\title{
Energy and Environment Chronology
}

\author{
David Hafemeister \\ Physics Department \\ California Polytechnic State University \\ San Luis Obispo, CA 93407
}

1859

—Edwin Drake drills 21 meters for 500 barrels of oil at Titusville, Pennsylvania, to begin the petroleum era.

- The rechargeable lead-acid battery is developed by Gaston Plante.

1870

—John D. Rockefeller founds Standard Oil.

1879

- Thomas Edison and J. Swan, independently, invent the incandescent lightbulb.

1882

—First US coal-fired power plant lights up Manhattan by Thomas Edison using DC voltage.

1908

-Model-T Ford runs on gas or ethanol, getting 21 miles per gallon.

1911

—Standard Oil Company monopoly is broken by the Supreme Court.

1930s

- General Motors, Firestone and Standard Oil of California buy US electric streetcar systems across and replace them with buses.

1942

—December 2: Enrico Fermi's reactor goes critical at Stagg Field, University of Chicago, Illinois to begin the nuclear era.

1945

-August 15: Office of Price Administration (OPA) lifts gasoline rationing.

1946

- May 6: Division of Oil and Gas established in Department of Interior.

- May 21: US President Harry Truman orders US Government to take possession of coal mines during a strike.

-June 18: National Petroleum Council established.

1947

-January 1: Atomic Energy Commission begins operation.

$$
\begin{gathered}
\text { Physics of Sustainable Energy II: Using Energy Efficiently and Producing it Renewably } \\
\text { AIP Conf. Proc. 1401, 447-454 (2011); doi: 10.1063/1.3653869 } \\
\text { (C) } 2011 \text { American Institute of Physics 978-0-7354-0972-9/\$30.00 }
\end{gathered}
$$


-March 25: Coal-mine disaster kills 11 In Centralia, Illinois.

-June 16: Federal Power Commission authority extended to all natural gas producers.

1952

—December 5: Severe air pollution (0.7 ppm SO and particulates) kills 4000 in London in 4 days.

1953

-August 7: Congress gives US government jurisdiction of ocean floors beyond 3-mile boundary.

-December 8: US President Dwight Eisenhower delivers "Atoms for Peace" speech before the United Nations.

1954

-August 30: Atomic Energy Act of 1954 encourages peaceful use of nuclear energy.

-Bell Labs develops the silicon photovoltaic cell.

1956

—Federal Highway system begins at a cost of $\$ 129$ billion.

1957

-King Hubbert correctly predicts US petroleum production peak between 1966-71, which happened in 1970 when lower forty-eight produced 9.1 Mbbl/day. Hubbert uses a finite resource in differential equations, but does not use economics.

1959

— March 10: Eisenhower limits oil imports to stimulate domestic production and refining capacity.

1962

-October 11: Congress authorizes the president to impose mandatory oil import quotas.

1963

-December 17: Clean Air Act provides assistance to states for air pollution research.

1965

-October 2: Water Quality Act establishes the Water Control Administration.

-October 20: Solid Waste Disposal Act provides assistance for study, collection, and disposal of solid wastes.

-November 9: First major power blackout covers northeast US.

1967

-November 21: Clean Air Act gives authority to Secretary of Health Education and Welfare to set auto emission standards.

1969

-January 1: National Environmental Policy Act (NEPA) establishes framework for Environmental Impact Statements and the Council of Environmental Quality (CEQ).

-January-February: Major oil spill from offshore drilling near Santa Barbara, CA.

-December 30: Oil depletion allowance reduced from $27.5 \%$ to $22 \%$.

1970

- March 5: President Richard Nixon issues executive order requiring federal agencies to evaluate their activities under the National Environmental Policy Act.

-April 22: First "Earth Day" celebration.

-July 9: Nixon requests Congress to create Environmental Protection Agency (EPA).

-October 23: Merchant Marine Act Amendment provides subsidies for oil and liquified natural-gas tankers. 
-December 24: Geothermal Steam Act authorizes leases for geothermal steam.

-Clean Air Act sets national air quality and auto emission standards.

1971

-July 23: Supreme Court decision on siting of nuclear power plant at Calvert Cliffs, Maryland, requires the Atomic Energy Commission to comply with the National Environmental Policy Act.

\section{2}

-EPA bans DDT.

- Clean Water Act sets pollution standards for water.

-US and Canada agree to clean up the Great Lakes, source of $95 \%$ of US fresh water, used by 25 million persons.

\section{3}

—June 29: White House Energy Policy Office created with former Governor John Love of Colorado as first "energy czar."

- October 17, 1973 to March 17, 1974: Organization of Petroleum Exporting Counties (OPEC) embargoes US and the Netherlands because of their support for Israel.

- November 7: Nixon creates Project Independence to end oil imports by 1980.

-November 27: Emergency Petroleum Allocation Act provides authority for oil allocations.

-December 4: Presidential Federal Energy Office created with William Simon as energy czar.

-December 15: Congress mandates daylight savings to save energy.

-December 28: Nixon signs Endangered Species Act.

-EPA begins phasing out leaded gasoline.

-EPA begins limits on factory pollution discharges.

\section{4}

-June 22: Federal Energy Administration (FEA) authorized to order utilities and industry to convert from oil/gas to coal.

- September 3: Congress authorizes funds for geothermal energy and solar heating demonstrations.

- October 5: Congress repeals daylight savings time in winter to save energy.

- October 11: Energy Reorganization Act abolishes the AEC to create the Energy Research and Development Administration (ERDA, later DOE) and the Nuclear Regulatory Commission (NRC).

-December 31: Congress requires ERDA to submit an annual comprehensive energy plan.

- Arthur Rosenfeld, establishes research on buildings and energy at Lawrence Berkeley National Laboratory, to begin the enhanced end-use efficiency energy era. Rosenfeld was the last graduate student of Enrico Fermi, who began the nuclear reactor era in 1942. The LBL work was originally based on the 1974-5 study by the American Physical Society.

\section{5}

-January 4: Congress establishes the 55-mph speed limit to save energy.

-March 17: Supreme Court rules that the states do not have jurisdiction over the outer continental shelf. - October 29: ERDA dedicated its first wind power system at Sandusky, Ohio.

-October: President Gerry Ford halts plans to reprocess US spent fuel at Barnwell, SC.

-December 22: Energy Policy and Conservation Act (EPCA) establishes prices for US crude oil, the Strategic Petroleum Reserve, emergency energy powers for the president, Corporate Average Fuel Economy (CAFE) standards of $27.5 \mathrm{mpg}$ by 1985 , and cost-effective, appliance energy standards.

-Introduction of catalytic converter mufflers for cars.

\section{6}

-April 5: Congress authorizes production from naval petroleum reserves.

-August 14: Energy Conservation and Production Act (ECPA) creates incentives for conservation and renewables, funds weatherization for low income homes, establishes a program for energy standards for new buildings and establishes Solar Energy Research Institute (now the National Renewable Energy Laboratory) to begin the renewable energy era. 
- Toxic Substance Control Act reduces environmental and human health risks. EPA begins phase out of PCBs.

1977

—April 7: President Jimmy Carter indefinitely defers reprocessing of nuclear fuel and stops construction of Clinch River Breeder Reactor.

—July 5: Solar Energy Research Institute (SERI) opens in Golden, Colorado; renamed in 1991 as the National Renewable Energy Laboratory (NREL).

- October 1: Department of Energy created from ERDA and the FEA. Jimmy Carter declares it is "the moral equivalent of war."

1978

-November 9: National Energy Act establishes weatherization grants for low income families, conservation programs for local governments, energy standards for consumer products, programs to convert utilities to coal, and energy tax credits.

- Buried, leaking containers found at Love Canal, NY; cleanup was completed in 1998.

- The Public Utilities Regulatory Policy Act (PURPA) of 1978 allows customers to sell electrical energy to electrical utilities on an avoided cost basis. Residential and commercial electricity producers can sell reliable, timely electrical energy at a rate lower than the utility can produce it.

1979

- March 28: Accident at Three Mile Island nuclear power plant in PA effectively halts purchase of new reactors in the US.

- Spring: Second oil shock from Iran oil curtailments causes gasoline shortages.

- August 17: President Carter begins to lift price controls on domestic crude oil.

- November 3: US embassy in Iran seized by revolutionaries; Carter suspends oil imports from Iran on November 14.

1980

-April 2: Windfall profit tax on crude oil to give assistance for weatherization of homes of low income people.

-June 30: Energy Security Act creates the Synthetic Fuels Corporation and funds renewable energy projects.

- Tax on certain chemicals creates a "superfund" to pay for cleanup when responsible parties fail.

1981

—January 28: President Ronal Reagan completes price decontrol on domestic crude oil.

-National Research Council finds acid rain intensifying in northeast US.

-1981-1985: Reagan and Congress debate funding for conservation programs.

1982

- May 24: Reagan proposes transfer of Department of Energy functions to the Department of Commerce.

1983

- Clean-up of Chesapeake Bay begins.

-EPA encourages homeowners to test for radon.

1984

-December 3: Chemical disaster at Union Carbide plant in Bhopal, India, kills 3000 and partially disables 2700 .

\section{5}

-February 4: Department of the Interior reduces estimates for offshore oil (27 to $12 \mathrm{Bbbl}$ ) and gas (163 to $91 \mathrm{tcf})$. 
-June 27: EPA modifies mileage test, lowering CAFE's $27.5 \mathrm{mpg}$ by $2 \mathrm{mpg}$.

- June 28: EPA curbs tall smokestacks to avoid distant pollution.

-July 16: Appellate Court confirms EPCA's appliance standards by voiding DoE's "no-standard" standard. A key issue was the magnitude of the discount rate for future benefits.

-Antarctic Ozone Hole for stratospheric ozone discovered.

1986

-April 26: Accident at Soviet reactor in Chernobyl, Ukraine.

-August 21: Large release of carbon dioxide from the depths of Lake Nyos, Cameron, kill 1800.

1987

- Montreal Protocol for ozone protection bans chlorofluorocarbons.

-December 27: Congress approves Yucca Mountain as the only high-level nuclear waste repository under development.

1988

- Congress bans ocean dumping of sewage sludge and industrial waste.

1989

- March 24: Exxon Valdez spill of 0.3 million barrels of oil in Prince William Sound, Alaska.

- March 23: Stanley Pons and Martin Fleishman announce discovery of "cold fusion." Physicists do not believe them.

1991

—January-February: Iraq sets 700 oil fires in Kuwait in wake of Gulf War.

-Exxon pays $\$ 1$ billion for Exxon Valdez spill.

1992

-EPA bans ocean dumping of sewage sludge.

-EPA launches Energy Star Program to identify energy efficient products.

1993

-EPA's Common Sense Initiative shifts OSHA regulations from pollution-based to industry-based.

-EPA research finds secondhand indoor cigarette smoke causes 3000 lung-cancer deaths per year to nonsmokers.

1994

-EPA launches Brownfields Program to restore abandoned city sites.

1995

- 70\% of US metropolitan areas that had unhealthy air in 1990 meet air quality standards in 1995.

1997

-EPA restricts particulate matter air emissions down to $2.5 \mu$ diameter.

- Kyoto Protocol to limit greenhouse gases (GHG) is agreed in principle by most nations, including the US, but the details for trading allotments of GHG are not certain.

1999

- Minivans and sport utility vehicles (SUVs) will have the same emission standards as cars.

-EPA requires cars, SUVs, minivans and trucks to have the same standards by 2004, reducing SUV pollution by $77-95 \%$.

- Honda sells the first commercial hybrid auto.

2000 
- Most utilities buy combined-cycle natural gas turbines at 55-60\% efficiency, a major supply side break through, establishing the natural gas era.

-California hit with rolling blackouts, stimulated by Enron maneuvers.

2001

-January: California's partial deregulation contributes to rolling blackouts caused by many factors.

- July 23: The Kyoto-Bonn Protocol on limiting GHG moved towards implementation, supported by

178 nations and the EU. Without support from the US, a former advocate turned critic, the future of the

Kyoto process is in doubt. The US stated it would use voluntary caps on GHG emissions.

- Sales of minivan and SUVs equal sales of cars.

- September 11: The World Trade Center in New York City is destroyed by two hijacked commercial aircraft. Some 3000 are killed at the WTC, the Pentagon and a field in Pennsylvania, and 360 firefighters are placed on mical leave or light-duty work. Mid-east oil will be more difficult to import.

2002

-February: President Bush proposed a voluntary 18\% carbon reduction by 2012 in terms of greenhouse gas intensity, which is the ratio of national total energy use of carbon fuels to GDP dollar.

-February 14: Secretary of Energy Spencer Abraham recommends approval of the Yucca Mountain, $\mathrm{NV}$, geological repository for 77,000 tonnes of nuclear spent fuel, to begin in 2010 .

-November: Bush Administration relaxes pollution standards on existing coal-fired power plants and gives managers of national forests more discretion to approve logging and commercial activities.

\section{3}

-April 1: CAFE standards for light-truck/SUVs rise from $20.7 \mathrm{mpg}$ to 21.0 in 2205, 21.6 in 2006 and $22.2 \mathrm{mpg}$ in 2007.

—June 7: The $18-\mathrm{GW}_{\mathrm{e}}$ Three Gorges Dam closes, to be completed by 2009, displacing 1.1 million people.

-August 11: Auto manufacturers no longer contest California's 2005-20 phase-in of low and zero emission vehicles.

- August 11: Gov. Michael Leavitt nominated to replace Gov. Christine Todd Whitman as EPA administrator.

-August 14: Electrical grid failure of $62 \mathrm{GW}_{\mathrm{e}}$ darkens 8 states and Canada (previously on 11-9-65 and 7-13-77).

- August 27: President Bush gives emission exemptions from the Clean Air Act for rehabilitated power plants.

2004

-Natural gas prices double and supplies from Canada become more uncertain. Coal plant orders rise from 2 to 100 and utilities request site approval for 3 nuclear plants.

-July 9: US Court of Appeals in DC rules against the 10,000-year limit on radiation safety at Yucca Mountain. The court concluded that EPA must either issue a revised standard that is "consistent with" the NAS peak-dose standard "or return to Congress and seek legislative authority to deviate from the NAS report."

- September 24: The California Air Resources Board required automobiles to lower carbon emissions by $30 \%$, to be phased in over 2009 and 2016. The Board claimed the extra cost would be $\$ 1000$ per vehicle, but it would save $\$ 2500$ in fuel. New York and other states claim they will follow suit.

-October 26: General Motors downsizes the Hummer from 6400 pounds (12 mpg) to 4700 pounds (16 city/20 highway).

-Kyoto climate change treaty goes into effect without US ratification.

2005

— January 19: A billion dollar LNG explosion at Skikda, Algeria clouds plans for $35 \mathrm{LNG}$ projects in the US.

-February 16: The Kyoto Protocol enters into force after Russian ratification. The 120 nations that ratified emitted $61 \%$ of greenhouse gases by signatories, over the $55 \%$ threshold for ratification. The 
US, which emits $37 \%$, did not ratify, while India and China did not sign. The carbon-trading allotments initially were selling for $\$ 10 /$ tonne.

-August 29-30: Katrina, a category 3 hurricane, floods 80\% of New Orleans, killing 1836 and costing $\$ 86$ billion (2007\$), the US's most expensive natural disaster.

-Energy Policy Act of 2005 modifies the Public Utilities Regulatory Policy Act of 1978 to include rules for net metering, time-based metering and the Smart Grid.

\section{6}

-Al Gore's documentary movie, An Unfortunate Truth, heightens concerns on carbon dioxide emissions from burning fossil fuels. Greenland glaciers and the North Polar Cap melt faster than expected.

2007

- January 10: European Union agrees to cut $\mathrm{CO}_{2}$ emissions by $20 \%$ by 2020 , compared to 1990 levels. Under the Kyoto protocol, the EU was already committed to an $8 \%$ decrease. The EU further agreed to make biofuels at least $10 \%$ of vehicle fuel by 2020 .

-April 2: US Supreme Court rules that states may regulate green house gasses in Massachusetts vs. EPA.

- CAFE auto standards raised from $27.7 \mathrm{mpg}$ to $35 \mathrm{mpg}$ by 2020 . California and other states lose in court to more the date forward on the grounds of cleaner air for their cities.

- Intergovernmental Panel on Climate Change (IPCC) 2007 conclusions: "Global mean surface temperatures have risen by $0.74{ }^{\circ} \mathrm{C}\left(+/-0.18^{\circ} \mathrm{C}\right)$ when estimated by a linear trend over the past 100 years (1906-2005)....Average Arctic temperature increased at almost twice the global average rate in the past 100 years....Sea levels rose 0.9 to $1.6 \mathrm{~mm} /$ year between 1993 and $2003 \ldots$...Carbon dioxide is increasing at $1.9 \mathrm{ppm} /$ year."

\section{8}

-July 9: The Group of Eight (G-8) of industrialized nations agree to cut greenhouse gases by $50 \%$ by 2050.

-December 22: Over a billion gallons of coal fly ash sludge flow from a holding dam near Kingsport, Tennessee. The sludge contains dangerous amounts of arsenic, boron, cadmium, cobalt, mercury, lead, selenium and other elements.

- Gasoline hits $\$ 4.50$ a gallon in the US, and twice that in many countries. SUV sales plummet.

- General Motors plans to introduce the Chevy Volt by about 2011 with an all-electric range of 40 miles with lithium ion batteries and an extended range from a 3-cycle engine. Toyota states it will follow, perhaps with nickel metal hydride batteries. EPRI points out that the un-used electricity at night can be put to good use on these proposals.

-Utilities propose to build some 30 nuclear power plants.

- China plans to build over 50 coal-fired power plants per year.

-British Petroleum gives Lawrence Berkeley Laboratory $\$ 500$ million to develop cellulosic fuels from switch grass. Corn food price rises as corn-ethanol for autos increases.

-Polymer photovoltaics hit 5\% efficiency, needing further research to enhance robustness.

- Refrigerators use less than $25 \%$ of former energy use. Movement towards green buildings expands, with the hope to have carbon-neutral buildings (with some local renewable energy).

\section{9}

-April 17: US EPA rules that the emissions of six greenhouse gases, including $\mathrm{CO}_{2}$, are a danger to the public and should be regulated under the Clean Air Act. This followed the April 2007 ruling of the Supreme Court.

-July 9: Prior to the Copenhagen negotiations, the G-8 nations (Canada, France, Germany, Italy, Japan, Russia, US and UK) agree to reduce greenhouse gases by $80 \%$ by 2050 .

-December 18: Climate negotiations collapse in Copenhagen as the Kyoto Protocol emissions treaty is set to expire in 2012. A non-binding agreement between Brazil, China, India, South Africa and the US is announced. 
2010

-March 25: The World Meteorological Organization states that the 2000-2009 decade was the warmest decade on record. This finding agrees with the US NASA's finding that the decade was the warmest since the 1850 's, when the first systematic records of temperatures were begun.

-An explosion at the West Virginia Upper Big Branch Mine killed 29 miners, the largest loss since the Kentucky Finley Coal Mine explosion in 1970, which killed 78. China, reportedly, losses 5,000 to 20,000 a year in mine explosions.

-April 20: The Deepwater Horizon drill rig in the Gulf of Mexico explodes, killing 11 and releasing 4.9 million barrels of oil over 100 days, devastating fragile coastal environments from Louisiana to Florida. Capping the well at a depth of $4 \mathrm{~km}$ proved illusive until partial containment on July 15 , and final plugging on September 19.1.8 million gallons of dispersant were used for the clean up.

-July 7: A panel of scientists at East Anglia University, UK concluded that allegations against the climate scientists were not valid, concluding that they acted with "rigor and honesty," but that they had failed "to display the proper degree of openness." A panel at Penn State University concluded the same result.

\section{1}

-January 13: EPA vetoes the water permit for the massive mountaintop removal at the Spence No. 1 site in West Virginia.

-January 15: EPA approves the use of $15 \%$ ethanol blended fuel, produced from corn.

- March 11: A 9.0 earthquake and 15-meter tsunami kill 20,000 and stop the cooling of 3 nuclear reactors, which partially melt. The three-month old low-enriched uranium and MOX spent fuels catch fire in cooling pond \#4. Replacement electricity for cooling pumps is not available for nine days. Reportedly, the amount of radiation released was $10 \%$ of that released at Chernobyl, which was more widely dispersed. Minor levels of radiation arrive in Tokyo, $200 \mathrm{~km}$ away. A massive and lengthy clean-up effort will be needed, with a large political impact on future energy supplies.

- The price of photovoltaic panels drops to under $\$ 0.80 /$ peak-Watt, perhaps $\$ 3-4$ total cost for large solar farms. About $10 \mathrm{GW}$ of serious proposals are made in the south-west US, with the aid of US loan guarantees.

-Energy Information Administration (EIA) data: Research on hydrodynamic fracturing of Devonian shale began in mid 1970's, and became economically competitive when combined with horizontal drilling in about 2005. US proved reserves of 273 trillion cubic feet are now extended with the hydrofracking (or fracking) technically recoverable reserves of $862 \mathrm{TCF}$. The impact on water supplies has yet to be resolved. At least 32 nations have these types of reserves. EIA projects that shale gas will grow from $14 \%$ of consumption in 2009 to $45 \%$ by 2035 , while imported gas will drop from $11 \%$ to $1 \%$.

-EIA projects US electricity production will grow from 3.7 trillion $\mathrm{kWh} / \mathrm{year}$ in 2009 to $4.9 \mathrm{TkWh} / \mathrm{yr}$ by 2035 . EIA projects only modest fuel shifts over these 26 years, with coal dropping slightly from $45 \%$ to $43 \%$, natural gas rising from $23 \%$ to $25 \%$, renewables rising from $10 \%$ to $14 \%$, and nuclear dropping from $20 \%$ to $17 \%$. The $3.7 \mathrm{TkWh} / \mathrm{yr}$ in 2009 corresponds to $420 \mathrm{GW}$ of average power, with $1.4 \mathrm{~kW} /$ person.

-EIA projects modest shifts in the total US consumption of energy from 2009 to 2035: coal remaining constant at $21 \%$, natural gas dropping from $25 \%$ to $24 \%$, petroleum dropping from $37 \%$ to $33 \%$, nuclear dropping from $9 \%$ to $8 \%$, renewables rising from $7 \%$ to $10 \%$, and liquid biofuels rising from $1 \%$ to $3 \%$. EIA projects a $5.6 \%$ rise in US $\mathrm{CO}_{2}$ emission from 5.98 billion tones/yr in 2005 to 6.31 in 2035.

-EIA projects that crude oil prices will rise from $\$ 60 /$ barrel to $\$ 133 /$ barrel within the wide range of $\$ 51$ and $\$ 210$. In 2009 , the total cost of energy per person was $\$ 3,400$ with $\$ 800$ for residential and $\$ 1,530$ for transportation. In 2008 , in a time with good employment and higher petroleum costs, transportation cost/person was $\$ 2,300$.

- In 2010, world-wide clean energy investments rose by $30 \%$ to $\$ 243$ billion, with $90 \%$ of this in the G-20 nations, with China investing the most with $\$ 54.4$ billion, Germany in second place with $\$ 41.2$ billion, and the US in the third place with $\$ 34$ billion (Pew Environmental Group). 